Materiales de Construcción

Vol. 68, Issue 330, April-June 2018, e155

ISSN-L: 0465-2746

https://doi.org/10.3989/mc.2018.00517

\title{
Physicochemical and radiological characterization of kaolin and its polymerization products
}

\author{
M. Ivanovića ${ }^{a}$, Lj. Kljajevića $₫$, M. Nenadovića ${ }^{a}$, N. Bundaleski ${ }^{\mathrm{a}}$, I. Vukanac ${ }^{\mathrm{a}}$, B. Todorović $^{\mathrm{b}}$, \\ S. Nenadović ${ }^{\mathrm{a}}$ \\ a. Institute of Nuclear Sciences "Vinča", University of Belgrade, (Belgrade, Serbia) \\ b. Faculty of Technology of Leskovac, University of Niš, (Niš, Serbia) \\ $\triangle$ ljiljanamkljajevic@gmail.com
}

Received 11 January 2017

Accepted 5 September 2017

Available on line 21 May 2018

\begin{abstract}
The aim of this study was determination of physical-chemical and radiological characteristics of kaolin and products of alkali-activated thermally treated kaolin (geopolymer). Also, the objective of presented research was to investigate the possibility of kaolin application as a pigment or as a raw material for obtaining geopolymer materials as a relatively new ones in a building material industry. Physicochemical characterization of one set of samples was conducted using X-ray diffraction (XRD), Fourier transform infra - red (FTIR) and X-ray photoelectron spectroscopy (XPS). Activity concentration of naturally occurring radionuclides in kaolin, metakaolin and geopolymer were determined. The absorbed dose rate (D) and the annual effective dose rate (EDR), calculated in accordance with the UNSCEAR 2000 report, are also presented in this paper. Kaolin was heat-treated on $750^{\circ} \mathrm{C}$ and specific activity of natural radionuclide in metakaolin increased up to 1.6, while measured specific activities in geopolymer were the lowest.
\end{abstract}

KEYWORDS: Metakaolin; Amorphous materials; Alkali-silica reaction; Curing; X-ray Diffraction (XRD);

Citation/Citar como: Ivanović, M.; Kljajević, Lj.; Nenadović, M.; Bundaleski, N.; Vukanac, I.; Todorović, B.; Nenadović, S. (2018) Physicochemical and radiological characterization of kaolin and its polymerization products. Mater. Construcc. 68 [330], e155 https://doi.org/10.3989/mc.2018.00517

RESUMEN: Caracterización físico-química y radiológica de un caolín y sus productos de polimerización. El objetivo de este estudio fue la determinación de las características físico-químicas y radiológicas del caolín y los productos resultantes de la activación alcalina (geopolímero). Además, el objetivo de la investigación fue investigar la posibilidad de la aplicación de caolín como pigmento o como materia prima para obtener materiales geopoliméricos relativamente nuevos en una industria de materiales de construcción. La caracterización fisicoquímica de las muestras se realizó mediante difracción de rayos X (XRD), espectroscopía infrarroja por transformada de Fourier (FTIR) y espectroscopía fotoelectrónica de rayos X (XPS). Se determinó la concentración de actividad de radionucleidos naturales en caolín, metacaolín y geopolímero. La tasa de dosis absorbida (D) y la tasa de dosis efectiva anual (EDR), calculada de acuerdo con el informe de UNSCEAR 2000, también se presentan en este trabajo. El caolín se trató térmicamente a $750^{\circ} \mathrm{C}$ y la actividad específica del radionucleido natural en el metacaolín aumentó hasta 1.6, mientras que las actividades específicas medidas en el geopolímero fueron las más bajas.

PALABRAS CLAVE: Metacaolin; Materiales amorfos; Reacción árido-alcali; Curado; Difracción de rayos X (XRD).

ORCID ID: M. Ivanović (http://orcid.org/0000-0002-1152-4171); Lj. Kljajević (http://orcid.org/0000-0002-06894645); M. Nenadović (http://orcid.org/0000-0003-1884-3981); N. Bundaleski (http://orcid.org/0000-0002-59582282); I. Vukanac (http://orcid.org/0000-0002-1225-250X); B. Todorović (http://orcid.org/0000-0002-0820-4513); S. Nenadović (https://orcid.org/0000-0003-4846-8801)

Copyright: (C) 2018 CSIC. This is an open-access article distributed under the terms of the Creative Commons Attribution 4.0 International (CC BY 4.0) License. 


\section{INTRODUCTION}

Research on the geopolymer synthesis binders from various raw materials has been greatly accelerated in the last few years; some examples from vitreous blast furnace slags, fly ashes and other byproducts are cited herein (1-6). The target was to design typically stable mixtures, either monoliths of flowable "concrete" and products which are already available in the market. In comparison to ordinary Portland cement, geopolymer concrete has better resistance to corrosion (7) and fire (up to approx. $\left.1300^{\circ} \mathrm{C}\right)(8)$, high compressive and tensile strengths, a rapid strength gain, lower shrinkage (9) and longer durability (10). Moreover, the carbon footprint of geopolymer concrete is significantly lower and has a large greenhouse gas reduction than that of similar products from Portland cement (11). Together with a process of technology using elevated temperatures, geopolymer binders seem to be suitable for selected building materials. In the civil engineering, building materials plays different roles, so they should possess corresponding properties. Various mineralogical and chemical compositions of raw materials result in different basic properties (physical-chemical, mechanical, and durability) of building materials (12). Since these materials are usually observed as naturally occurring radioactive materials (NORM), radiological aspect in their usage as building materials should also be taken into the consideration.

Additionally, during the technologically enhanced processing of NORM, specific activity in by-products could increase significantly. These by-products are potential raw materials in manufacture of geopolymer binders (13). Determination of natural radionuclides content in building materials is important in order to estimate the exposure of humans to radiation, who can spend up to $80 \%$ of their time indoors (14). The radiation of terrestrial origin in buildings does not only originate from the soil (15-21), but also from the used building materials (22). Over the last few decades radiological research related to construction materials and buildings and their impact on the human health are supported. The building materials strongly influence indoor levels of the radioactive gas radon - direct progeny of ${ }^{226} \mathrm{Ra}$, and its decay products, which contribute significantly to doses through inhalation. It is shown by international studies, of the WHO (23) and ICRP (24), that building materials have a nonnegligible share of radiation exposure of the public due to radon. Depending on the material, the concentration of natural radionuclides (mainly ${ }^{226} \mathrm{Ra}$, ${ }^{232} \mathrm{Th}$ and ${ }^{40} \mathrm{~K}$ ) ranges from 1 to $4000 \mathrm{~Bq} / \mathrm{kg}(19,20)$.

The focus of this research was kaolin located below of soil that was subject of our previously published paper (25), and its polymerization products geopolymers. Structural characteristics of the precursor materials and the geopolymer samples have been investigated by using various analytical techniques. FTIR and XPS analysis were used to monitor the forming of new chemical bonds during the synthesis of geopolymer as the potential building materials. Gamma spectroscopy measurements of the set of samples (kaolin, metakaolin and geopolymer) revealed the activity of natural radionuclides ${ }^{226} \mathrm{Ra},{ }^{232}$ Th and $\left.{ }^{40} \mathrm{~K}\right)$.

\section{EXPERIMENTAL}

\subsection{Materials and methods}

\subsubsection{Materials}

The used kaolin is high clay obtained from Rudovci, Lazarevac, Serbia. Physicochemical properties of kaolin were investigated in previous work Nenadović et al. (25). It was shown that the structural characteristics of this kaolin are suitable for both, mechanochemical and thermal treatments planned in this research. Reduction of the main particle size and changes in the ordered crystalline structure of the raw kaolin was done by mechanical milling in a Turbula Type T2C Mixer. The milling was performed under argon using ball-to-powder ratio (BRP) 4. Metakaolin (MK) was prepared by calcining kaolinite at $750{ }^{\circ} \mathrm{C}$ for $3 \mathrm{~h}$. The alkaline solution was prepared from sodium silicate (volume ratio $\mathrm{Na}_{2} \mathrm{SiO}_{3} / \mathrm{NaOH}=1.6$ ) and $16 \mathrm{M} \mathrm{NaOH}$ (analytical grade). The reference geopolymer (GP) was formed from metakaolin and the alkaline solution (solid/liquid ratio was 0.85 ), which were mixed for $10 \mathrm{~min}$ and then left at room temperature for one day. Finally, the mixture was kept in a sample drying oven for 2 days at $50{ }^{\circ} \mathrm{C}$. Time of 28 days is necessary to complete the process of polymerization.

\subsubsection{XRD analysis}

All samples were characterized using X-ray diffractometry (XRD) by using Ultima IV Rigaku diffractometer, equipped by $\mathrm{Cu} \mathrm{K} \alpha_{1,2}$ radiation, with generator voltage $40.0 \mathrm{kV}$ and generator current $40.0 \mathrm{~mA}$. The range from $5^{\circ}$ up to $80^{\circ} 2 \theta$ angle was used for all powders in a continuous scan mode with a scanning step size of $0.02^{\circ}$ at scan rate of $10 \% \mathrm{~min}$.

\subsubsection{FTIR analysis}

The functional groups of samples (kaolin, metakaolin, geopolymer) were studied using FTIR spectroscopy. Samples were powdered finely and dispersed evenly in anhydrous potassium bromide $(\mathrm{KBr})$ pellets $(1.5 \mathrm{mg} / 150 \mathrm{mg} \mathrm{KBr})$. Spectra were taken at room temperature using a Bomem (Hartmann \& Braun) MB-100 spectrometer set to give accurate spectra. The spectral data of the samples were collected in $4000-400 \mathrm{~cm}^{-1}$ region. 


\subsubsection{XPS analysis}

XPS analysis has been performed using a SPECS system for surface characterization. The samples in the form of powder were fixed on an adhesive tape and analyzed "as received". Photoelectron emission has been excited by monochromatic $\mathrm{Al} \mathrm{K}_{\alpha}$ line having photon energy equal to $1486.67 \mathrm{eV}$. Survey spectra were taken in fixed analyzer transmission mode with pass energy of $40 \mathrm{eV}$ (FAT 40) with energy step of $0.5 \mathrm{eV}$ and the dwell time of $0.2 \mathrm{~s}$. Detailed spectra of the main photoelectron lines were taken in FAT 20 mode with the energy step of $0.1 \mathrm{eV}$ and the dwell time of $2 \mathrm{~s}$. Charge compensation was performed using the electron flood gun, and the binding energy axis was fitted according to the position of the carbon $\mathrm{C}$ 1s line, assuming its main contribution corresponds to adventitious carbon situated at $284.8 \mathrm{eV}$. The composition analysis has been performed according to the characteristic photoelectron line intensities after background removal, using the atomic sensitivity factors provided by the manufacturer. The photoelectron lines were fitted to the superposition of peaks having pseudo-Voigt GL (30\% Lorentzian, $70 \%$ Gaussian) profiles. Each contribution in the frame of the same line was considered to have the same width. The intensity ratio between the peaks attributed to the same bond of $2 p_{3 / 2}$ and $2 p_{1 / 2}$ lines has fixed intensity ratio $2: 1$, as predicted by the theory. Spin-orbit splitting of Si $2 p$ and $\mathrm{Al} 2 \mathrm{p}$ lines was fixed during the fitting to $0.6 \mathrm{eV}$ and $0.4 \mathrm{eV}$, respectively.

\subsubsection{Gamma ray spectrometry}

The naturally occurring radionuclides in the samples of kaolin, metakaolin and geopolymer were determined by gamma ray spectrometry. The samples were mechanically prepared, meaning that they have been mechanically milled for the purposes of other analytical method used for sample characterization. Pulverized samples were placed in PVC cylindrical containers $(125 \mathrm{ml})$ and sealed in order to reach radioactive equilibrium between ${ }^{226} \mathrm{Ra}$ and its daughter products for six weeks.

Radiological analysis was performed by means of a coaxial semiconductor high purity germanium (HPGe) detector (AMETEK-AMT ORTEC GEM30-70, with 37\% relative efficiency and $1.8 \mathrm{keV}$ resolution for ${ }^{60} \mathrm{Co}$ at the $1332 \mathrm{keV}$ line) associated with standard beam supply electronic units. Energy and efficiency calibration were performed with soil and coal standards prepared with certified solution of mixed gamma-emitting radionuclides ${ }^{241} \mathrm{Am}$, ${ }^{109} \mathrm{Cd},{ }^{139} \mathrm{Ce},{ }^{57} \mathrm{Co},{ }^{60} \mathrm{Co},{ }^{137} \mathrm{Cs}$, ${ }^{203} \mathrm{Hg},{ }^{113} \mathrm{Sn},{ }^{85} \mathrm{Sr}$, and ${ }^{88} \mathrm{Y}$ ), purchased from the Czech Metrology Institute (CMI). Technique of standard preparation was described in previously published paper (26). Used radioactivity standards were of the adequate density and similar chemical composition. Calibration of the spectrometer was conducted in accordance with an IAEA recommendation (27). Obtained efficiencies were corrected for coincidence summing effect using the correction factors described by Debertin and Schötzing (28).

Experimentally obtained efficiency curves had the analytical expression $\varepsilon=e^{-P(\ln E)}$ where $\varepsilon$ is the detection efficiency, $E$ is the energy and $P(\ln E)$ is the polynomial function of the fifth order. All the calculations and fitting were performed in Mathematica 5.2 software (Wolfram Research). Uncertainty of the efficiency calibration includes uncertainty of the activity of radionuclides in prepared standard, statistical uncertainty and fitting uncertainty of efficiency curve.

After reaching radioactive equilibrium, samples were measured and all spectra were recorded and analyzed using the Canberra's Genie 2000 software. The measurement times were $80000 \mathrm{~s}$. Net areas of the relevant full energy peaks were corrected for the background, dead time and coincidence summing effects. Due to high resolution of the HPGe spectrometer used, full energy peaks were well separated, except in the cases described in below.

Activity concentration of ${ }^{238} \mathrm{U}$ was determined indirectly by analyzing full energy peaks emitted by its descendants, ${ }^{234 \mathrm{mPa}}(1001 \mathrm{keV})$ and ${ }^{234} \mathrm{Th}(63.3$ $\mathrm{keV})$. The contribution of ${ }^{232} \mathrm{Th}$ at $63.811 \mathrm{keV}$ to the 63.3 keV ${ }^{234}$ Th peak was neglected. Activity of ${ }^{235}$ $\mathrm{U}$ was determined directly via full energy peak at $143.767 \mathrm{keV}$. Since the samples were equilibrated, the activity of ${ }^{226} \mathrm{Ra}$ was determined via its decay products ${ }^{214} \mathrm{Bi}(609.31 \mathrm{keV}, 1120.3 \mathrm{keV}, 1764.5 \mathrm{keV})$ and ${ }^{214} \mathrm{~Pb}(295.21 \mathrm{keV}, 351.92 \mathrm{keV})$. Additional testing was performed via $186.211 \mathrm{keV}$ peak corrected for ${ }^{235} \mathrm{U}(185.72 \mathrm{keV})$ contribution since these peaks cannot be resolved due to its close energies. The activity of ${ }^{210} \mathrm{~Pb}$ was determined by analyzing its low energy peak at $46.54 \mathrm{keV}$.

The activity of ${ }^{232} \mathrm{Th}$ was determined through the calculated activity of its progeny ${ }^{228} \mathrm{Ac}(338.42 \mathrm{keV}$; $911.16 \mathrm{keV} ; 968.97 \mathrm{keV})$. Obtained results was than additionally checked through other radionuclides from the thorium series, ie. ${ }^{212} \mathrm{Bi}(727.25 \mathrm{keV})$ and ${ }^{212} \mathrm{~Pb}(238.58 \mathrm{keV})$.

The activity of ${ }^{40} \mathrm{~K}$ was determined directly by analyzing net peak area at $1460.8 \mathrm{keV}$, subtracted for the contribution of ${ }^{228} \mathrm{Ac}(1459.3 \mathrm{keV})$, which could not be resolved in the recorded spectra.

Specific activities obtained are given in Table 3, expressed in $\mathrm{Bq} / \mathrm{kg}$. Presence of artificial radionuclides, gamma emitters, was not detected. Since the presence of ${ }^{137} \mathrm{Cs}$ could be expected in environmental samples, as a result of radio pollution, detection limits for this radionuclide are also given in Table 3.

Quoted uncertainties (the confidence level of $1 \sigma$ ) were calculated by error propagation calculation 
using the Mathematica 5.2 software (Wolfram Research). The combined standard uncertainties included the efficiency calibration uncertainty and the statistical uncertainties of the recorded peaks.

\subsubsection{Dose assessment}

Radium equivalent activity, $\mathrm{Ra}_{\mathrm{eq}}\left(\mathrm{Bq} \mathrm{kg}^{-1}\right)$, the external hazard index, $H_{e x}\left(\mathrm{~Bq} \mathrm{~kg}^{-1}\right)$, total external absorbed gamma dose rate $D(\mathrm{nGy} / \mathrm{h})$, and annual effective dose rate $E D R\left(\mathrm{mSv} \mathrm{y}^{-1}\right)$ in measured samples were calculated. The radium equivalent activity was used to estimate hazard associated with materials that contain ${ }^{226} \mathrm{Ra},{ }^{232} \mathrm{Th}$ and ${ }^{40} \mathrm{~K}$. The external radiation hazard index reflects external radiation hazard due to the emitted gamma radiation. The values of these indicators of exposure were calculated according to Eqs. [1] and [2], (13, 29, 30):

$\mathrm{Ra}_{\mathrm{eq}}=\mathrm{A}_{\mathrm{Ra}}+1.43 \mathrm{~A}_{\mathrm{Th}}+0.077 \mathrm{~A}_{\mathrm{K}}$

$\mathrm{H}_{\mathrm{ex}}=\left(\mathrm{A}_{\mathrm{Ra}} / 370\right)+\left(\mathrm{A}_{\mathrm{Th}} / 259\right)+\left(\mathrm{A}_{\mathrm{K}} / 4180\right)$

respectively, where:

$\mathrm{A}_{\mathrm{Ra}}$ denotes specific activity of ${ }^{226} \mathrm{Ra}$ in $\mathrm{Bq} / \mathrm{kg}$

$\mathrm{A}_{\mathrm{Th}}$ denotes specific activity of ${ }^{232} \mathrm{Th}$ in $\mathrm{Bq} / \mathrm{kg}$, and $\mathrm{A}_{\mathrm{K}}$ denotes specific activity of ${ }^{40} \mathrm{~K}$ in $\mathrm{Bq} / \mathrm{kg}$.

The external terrestrial gamma radiation absorbed dose rate, $D$, in air at a height of $1 \mathrm{~m}$ above ground level due to radionuclides ${ }^{226} \mathrm{Ra},{ }^{232} \mathrm{Th}$ and ${ }^{40} \mathrm{~K}$ in measured samples was calculated using Eq. [3], and conversion factors: $0.462(\mathrm{nGy} / \mathrm{h}) /(\mathrm{Bq} / \mathrm{kg})$ for ${ }^{226} \mathrm{Ra}, 0.604(\mathrm{nGy} / \mathrm{h}) /(\mathrm{Bq} / \mathrm{kg})$ for ${ }^{232} \mathrm{Th}$ and 0.0417 $(\mathrm{nGy} / \mathrm{h}) /(\mathrm{Bq} / \mathrm{kg})$ for ${ }^{40} \mathrm{~K}(14)$

$D=0.462 A_{R a}+0.604 A_{T h}+0.0417 A_{k}$

The annual outdoors effective dose rate, EDR $(\mathrm{mSv} / \mathrm{y})$ Eq. [4], was calculated utilizing a conversion coefficient of $0.7 \mathrm{~Sv} / \mathrm{Gy}$ to convert the absorbed dose in air into the effective dose in the human body. This calculation takes into account that people spend about $20 \%$ of the time outdoors (outdoor occupancy factor $\mathrm{p}$ is 0,2 ) and $\mathrm{t}$ is 8,760 $\mathrm{h}$ annual exposure time. Thus, the annual effective dose rate, EDR, due to gamma radiation was calculated as, (14):

$\operatorname{EDR}(\mathrm{mSv} / \mathrm{y})=D(\mathrm{nGy} / \mathrm{h}) \cdot t \cdot p(\mathrm{~h} / \mathrm{y}) 0.7(\mathrm{~Sv} / \mathrm{Gy}) 10^{-6}$

Previous calculation is performed under assumption that measured samples occurs in the environment. Based on the fact that investigated materials are row materials, and not necessarily meant for usage in construction industry, absorbed dose rate and annual effective dose rate were calculated using the equations [3] and [4], respectively.

If the examined materials are treated as a possible raw material for building material or construction material itself, different formulae should be used for dose calculation. Using the formulae given in (31), external dose rate and annual effective dose rate are calculated as [5] [6]:

$D=0.92 A_{R a}+1.1 A_{T h}+0.08 A_{k}$, and

$\mathrm{EDR}(\mathrm{mSv} / \mathrm{y})=D(\mathrm{nGy} / \mathrm{h}) \cdot 7000 h 0.7(\mathrm{~Sv} / \mathrm{Gy}) 10^{-6}$

Nevertheless, the percentage of examined row material, in addition to other constituents in final building material should be taken into account.

\section{RESULTS AND DISCUSSION}

\subsection{XRD analysis}

Figure 1 shows the XRD patterns of the kaolin, metakaolin and geopolymer samples. According to the identified XRD patterns, the mineral phases identified in the as-received kaolin sample are kaolinite, muscovite and quartz (Fig. 1a). In the case of the thermally treated sample of kaolinite i.e. metakaolin, diffraction peaks of muscovite and in particular kaolinite were reduced, thus leaving quartz phase as the dominant one (Fig. 1b).

Metakaolin, in contrast to kaolin (25), was composed of amorphous phase and semi crystalline structure. Quartz could be identified as a component of metakaolinite. Appearance of the broad band between $18^{\circ}$ and $25^{0}$ indicated that the geopolymer prepared in this experiment was almost composed of amorphous structure. Obviously, quartz in the metakaolin is not solved in the geopolymerization

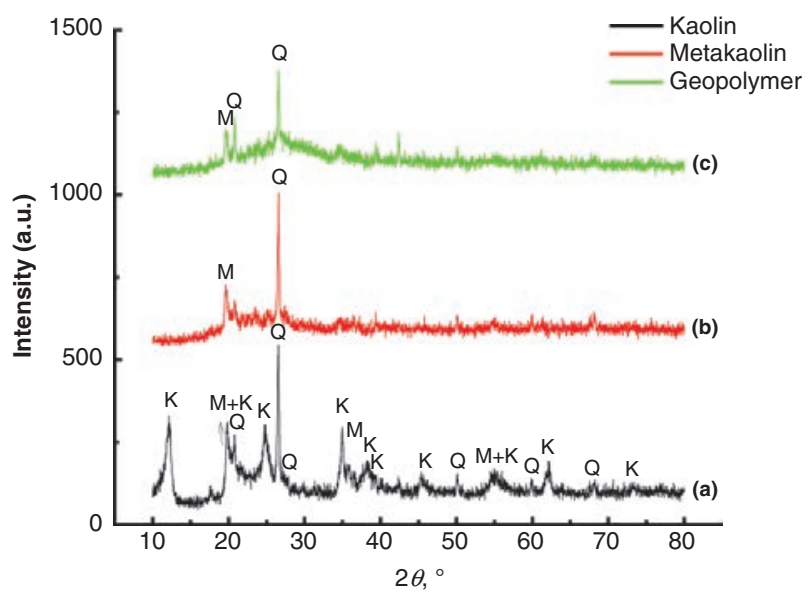

FIGURE 1. XRD patterns of a) kaolin, b) metakaolin $(\mathrm{MK})$, and c) geopolymer (GP) (K-kaolinite, M-muscovite $\mathrm{KAl}_{2}$, Q-quartz $\mathrm{SiO}_{2}$ ]. 
reaction but its intensities were slightly lower due to a dilution effect. Quartz sharp peak was, most probably, the impurity in the calcined clay. According to Davidovits (32) geopolymers that harden at ambient temperatures remain X-ray amorphous and they are the geopolymers of practical interest and he works on geopolymerization mechanisms, microstructure development, properties and the application development of geopolymers as green building material.

\subsection{FTIR analysis}

The results of the FTIR analysis of the studied samples are presented in Fig. 2. The FTIR absorption spectra were compared to known absorption lines in literature.

The FTIR spectrum of the kaolinite is typical of Al-kaolinite with four characteristic $\mathrm{OH}$-stretching vibrations at $3696,3668,3650$ and $3620 \mathrm{~cm}^{-1}\left(\mathrm{vAl}_{2} \mathrm{OH}\right)$ $(33,34)$. In the $1400-400 \mathrm{~cm}^{-1}$ range (Figure 2), the $\gamma \mathrm{Si}-\mathrm{O}$ stretching vibrations of kaolinite are clearly observed at 1104, 1033, and $1010 \mathrm{~cm}^{-1}$. Spectrum also contains a band at $798 \mathrm{~cm}^{-1}$ that is attributed to

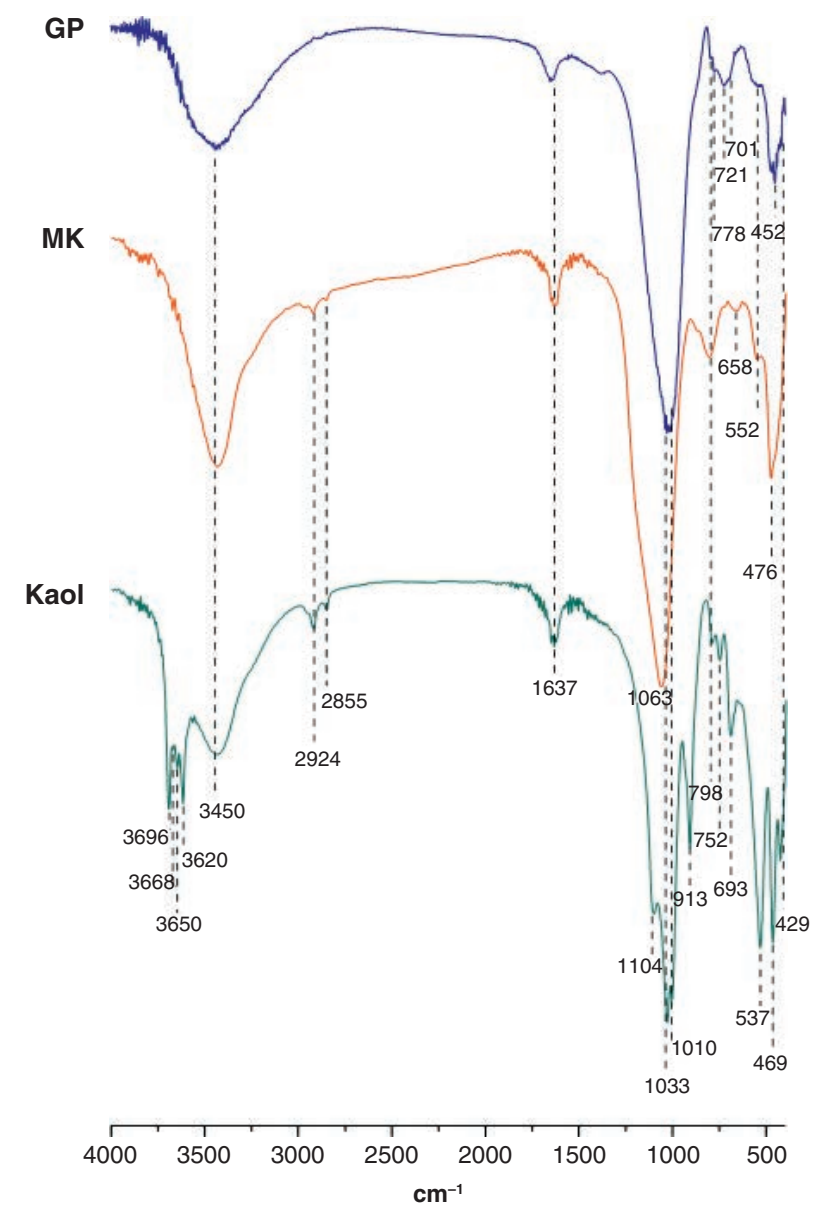

FIGURE 2. FTIR spectrum of kaolin (Kaol), metakaolin (MK) and geopolymer (GP) samples. quartz $(35,36)$. The intensity band at $913 \mathrm{~cm}^{-1}$ is from the Al-Al-OH groups. The bands at 752 and $693 \mathrm{~cm}^{-1}$ correspond to $\gamma \mathrm{Si}-\mathrm{O}$ stretching (37) while at $537 \mathrm{~cm}^{-1}$ correspond to $\gamma \mathrm{Si}-\mathrm{O}-\mathrm{Al}$ (octahedral) stretching, and those at 469 and $427 \mathrm{~cm}^{-1}$ correspond to $\delta \mathrm{Si}-\mathrm{O}$ and related $\mathrm{Si}-\mathrm{O}-\mathrm{Si}$ (38). This diversity of bands could be due to the presence of other aluminosilicates in the sample (illite and K-feldspars).

Heating of the kaolinite samples to metakaolin at $750{ }^{\circ} \mathrm{C}$, the sharp $\mathrm{OH}$ bands in the typical OH-stretching band range $\left(3000-4000 \mathrm{~cm}^{-1}\right)$ have completely disappeared. Also no sharp $\mathrm{OH}$ peaks in this area although the $16 \mathrm{M} \mathrm{NaOH}$ was used to obtain geopolymer sample. The bands at 1104 , 1033 , and $1010 \mathrm{~cm}^{-1}$ for Si-O stretching, those at 913,752 and $537 \mathrm{~cm}^{-1}$ also disappear. The increase in the band intensity at $1063 \mathrm{~cm}^{-1}$ suggests that a three-dimensional network of amorphous $\mathrm{Si}-\mathrm{O}-\mathrm{Si}$ units is formed. These observations are in agreement with the XRD results, which demonstrate that the kaolinite structure is destroyed.

\subsection{XPS analysis}

XPS analysis of aluminosilicates is a challenging task. The photoelectron lines are broadened due to the non-uniform surface charging, and the binding energy calibration is not always reliable. The problem becomes more elusive in case of working with natural materials, typical consisting of different phases. In this specific case, XRD analysis already shown that the kaolin sample contains significant amounts of quartz. Therefore, its presence can be expected in all samples.

Composition analysis of kaolin, metakaolin and geopolymer samples is presented in Table 1. Carbon, originating from hydrocarbon surface impurities (so-called adventitious carbon), is present in all samples. As already stated, the position of its $\mathrm{C} 1 \mathrm{~s}$ line is used as the binding energy reference.

According to the XRD analysis, kaolin represents a mixture of different (alumino) silicate phases, in which kaolinite and quartz are dominant. Since the $\mathrm{Si} / \mathrm{Al}$ ratio in kaolinite should equal 1 , the difference between the amounts of silicon and aluminum can be used to estimate the atomic percentages of kaolinite $\left(\mathrm{Si}_{2} \mathrm{Al}_{2} \mathrm{O}_{5}(\mathrm{OH})_{4}\right)$, metakaolin $\left(\mathrm{Si}_{2} \mathrm{Al}_{2} \mathrm{O}_{7}\right)$ and quartz $\left(\mathrm{SiO}_{2}\right)$. The ratio between the atomic percentages of kaolinite and quartz is about 5 in the kaolin sample, whilst that of metakaolin and quartz

TABLE 1. XPS composition analysis of kaolin and metakaolin (MK) and geopolymer (GP) samples

\begin{tabular}{lccccc}
\hline Sample & C (\%) & O (\%) & Si (\%) & Al (\%) & Na (\%) \\
\hline Kaolin & 2.0 & 60.4 & 23.3 & 14.3 & \\
MK & 1.1 & 58.4 & 24.1 & 16.4 & \\
GP & 9.6 & 63.5 & 14.7 & 7.8 & 4.0 \\
\hline
\end{tabular}


in MK sample is about 3.9. The observed difference can be qualitatively explained by the loss of water when transforming kaolinite into metakaolin. The relative amount of quartz in GP sample (observed by XRD and FTIR) cannot be determined this way, because the chemical composition of the geopolymer is unknown at this point. As for the kaolin and MK samples, it is also clear that the relative amounts of oxygen is lower than expected, which is quantified below according to the detailed analysis of the characteristic photoelectron lines. The presence of sodium in the GP sample is an evidence of $\mathrm{ONa}$ groups, which, along with $\mathrm{OH}$ groups, typically end geopolymer chains.

Analysis of the Si $2 p$ line confirms the presence of kaolinite and quartz contributions having $\mathrm{Si} 2 \mathrm{p}_{3 / 2}$ lines at about $102.6 \mathrm{eV}$ and $103.8 \mathrm{eV}$, respectively $(39,40)$. The ratio between the amounts of silicon in kaolinite and in quartz was used as a constraint in fitting the Si $2 p$ line taken from kaolin and MK samples. The Si $2 p$ line taken from the MK sample is shown in Figure 3. Al $2 p$ line in these samples consists of a single contribution at about $75.0 \mathrm{eV}$, which can be attributed to both, Al-O and Al-OH bonds (41). Finally, $\mathrm{O} 1 \mathrm{~s}$ line was resolved into three contributions attributed to $\mathrm{Al}-\mathrm{O}$ and $\mathrm{Al}-\mathrm{OH}$ bonds at about $531 \mathrm{eV}$ (41), Si-O bonds at 531-532 eV (42) and to quartz at about $533 \mathrm{eV}$ (40). The spectrum of the $\mathrm{O} 1 \mathrm{~s}$ line taken from the kaolin sample is presented in Figure 4.

The corresponding fitting results for the two samples are summarized in Table 2. It can be observed that the relative intensity of the peak attributed to $\mathrm{Al}-\mathrm{OH}$ bonds (contribution1) is smaller in $\mathrm{MK}$ as compared to kaolin. This can be explained by the loss of $\mathrm{OH}$ groups, which are dominantly bound to $\mathrm{Al}$ atoms, during the synthesis of $\mathrm{MK}$. The ratio between the oxygen and silicon amounts in quartz of both samples is about 1.8, revealing already mentioned deficiency of oxygen in this phase.

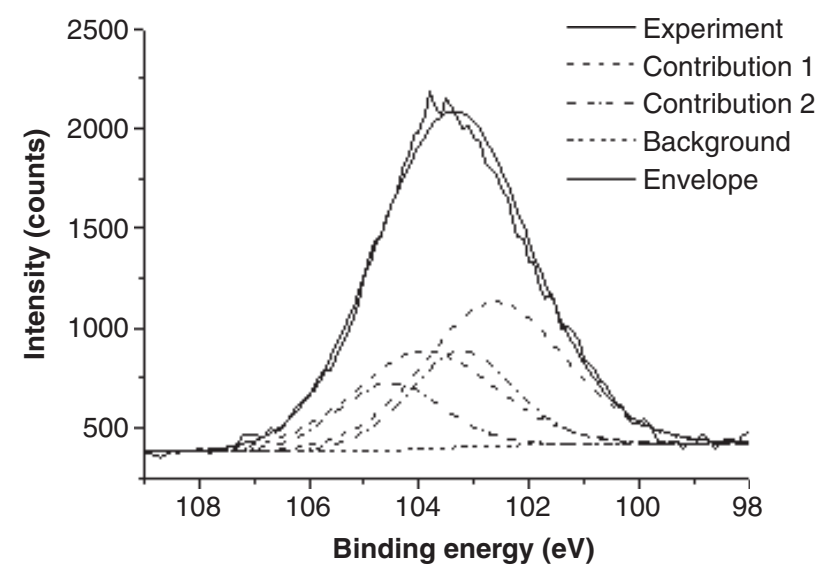

FIGURE 3. XPS spectrum of the Si $2 p$ line taken from the MK sample and the fitting result.
Al $2 p$ and Si $2 p$ lines taken from the GP sample consist of a single and two contributions, respectively. $\mathrm{Al} 2 \mathrm{p}_{3 / 2}$ is situated at $74.5 \mathrm{eV}$, which fits perfectly to the position of this line in geopolymers synthesized from metakaolin (43). Si 2p line was resolved to the contributions attributed to geopolymers (at $102.3 \mathrm{eV}$ ) and quartz (at $103.5 \mathrm{eV}$ ) with relative intensities of $77.8 \%$ and $22.2 \%$, respectively The geopolymer contribution is above the one obtained in (43) for about $0.8 \mathrm{eV}$. However, the position of this line strongly depends on the amount of sialate bonds in the geopolymer. Indeed, in the case of pure siloxo bonds, $\mathrm{Si} 2 \mathrm{p}_{3 / 2}$ line is situated at $103.8 \mathrm{eV}$ (42). After subtracting the amount of silicon bound in quartz, the ratio between the $\mathrm{Si}$ and $\mathrm{Al}$ concentrations in geopolymer was evaluated to be 1.47 . This ratio clearly suggests that the geopolymer sample consists of the roughly equal amounts of siloxo ( $\mathrm{Si}-\mathrm{O}-\mathrm{Si})$ and sialate $(\mathrm{Si}-\mathrm{O}-\mathrm{Al})$ bonds.

$\mathrm{O}$ 1s line taken from GP samples, presented in Figure 5, was resolved into three contributions, which is usual for the geopolymers (43). Two of them can be readily attributed to $\mathrm{Si}-\mathrm{ONa}$ (at $529.6 \mathrm{eV}$, relative intensity of $15.9 \%$ ) and silanol $\mathrm{Si}-\mathrm{OH}$ bonds $(532.8 \mathrm{eV}$, rel. int. $22.5 \%)$. The latter contribution is also attributed to quartz. The peak at $531.2 \mathrm{eV}$ with the relative intensity of $61.6 \%$, is typically related to the mixture of siloxo ( $\mathrm{Si}-\mathrm{O}-\mathrm{Si})$ and sialate $(\mathrm{Si}-\mathrm{O}-\mathrm{Al})$ bonds. This is an additional confirmation of the conclusions made from the composition and $\mathrm{Si} 2 \mathrm{p}$ line analyses concerning the structure of the synthesized geopolymer. Assuming that the stoichiometry of the quartz phase in this sample is the same as in kaolin and $\mathrm{MK}$ samples $(\mathrm{O}: \mathrm{Si}=1.8)$, the estimated

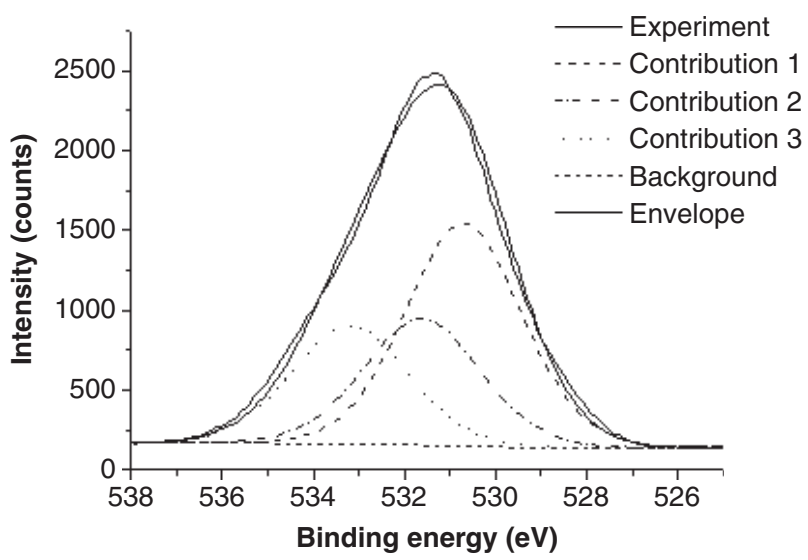

FIGURE 4. XPS spectrum of the $\mathrm{O}$ 1s line taken from the kaolin sample and the corresponding fit.

TABLE 2. Fitting results of the $\mathrm{O}$ 1s line taken from kaolin and MK

\begin{tabular}{llll}
\hline Sample & Contrib. 1 & Contrib. 2 & Contrib. 3 \\
\hline Kaolin & $530.7 / 47.6$ & $531.6 / 21.1$ & $533.2 / 25.3$ \\
MK & $531.0 / 37.9$ & $532.3 / 37.3$ & $533.1 / 24.8$ \\
\hline
\end{tabular}


stoichiometry of the geopolymeric chains is $75.0 \%$ of $\mathrm{O}, 14.8 \%$ of $\mathrm{Si}$ and $10.2 \%$ of $\mathrm{Al}$.

\subsection{Radiological analysis}

\subsubsection{Gama spectrometric analysis}

Results of gamma spectrometric analysis conducted in a manner described in chapter 2.1. are given in Table 3, and based on these values dose calculations were performed.

Measured specific activity of natural radionuclides has significantly different values for three measured samples. In addition, radionuclide content showed enhancement after the first stage of polymerization, when kaolin was thermally treated on $750{ }^{\circ} \mathrm{C}$ and changed into a metakaolin phase (confirmed by FTIR analysis, XRD and XPS). The ratio of natural radionuclides content in metakaolin, compared to raw kaolin is in the range from

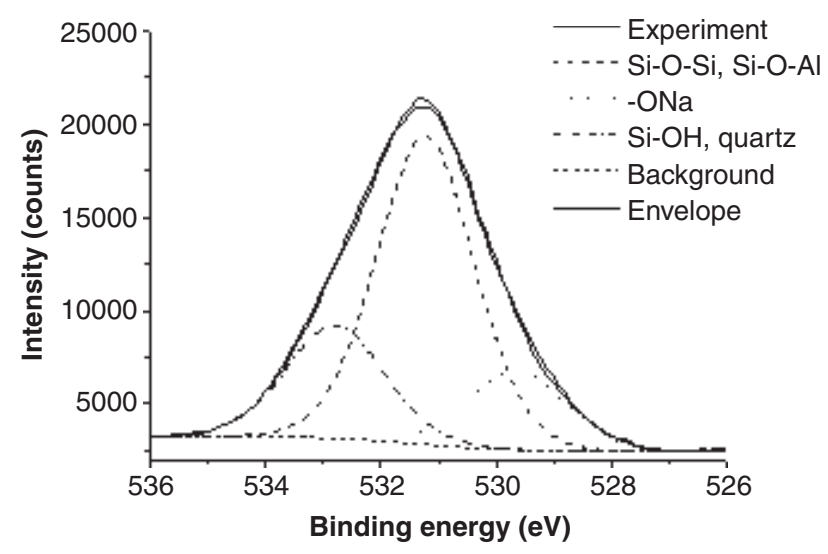

FIGURE 5. XPS spectrum of the O 1s line taken from the GP sample and the corresponding fit
1.11 to 1.60 . The lowest ratio is recorded for natural isotopes ${ }^{40} \mathrm{~K}$, while the highest ratio was recorded at the isotope ${ }^{214} \mathrm{~Pb}$. Further polymerization process, when it comes to alkaline activation of metakaolin (in our case with $16 \mathrm{M} \mathrm{NaOH}$ ), lead to a further change (in opposite direction) of radionuclide content in measured geopolymer.

After 28 days, time necessary to complete the process of polymerization, FTIR, XPS and XRD analysis have confirmed the existence of synthesized geopolymer material. The ratio of natural radionuclides content in the synthesized material and the natural material is in the range from 0.52 to 0.72 . The highest ratio of natural radioactivity is recorded for the isotopes ${ }^{214} \mathrm{~Pb}$, and the lowest for the isotope ${ }^{235} \mathrm{U}$.

The difference of the masses, i.e. densities, between kaolin and metakaolin due to loss of moisture in the sample was $8.3 \%$. Mass of the geopolymer sample was $8.4 \%$ lower than mass of kaolin. These values do not correspond to measured activity ratios. This would mean that, in addition to loss of moisture, a further influence on the specific activities should be sought in the different physicochemical properties of nuclides of the uranium and thorium series, resulting in a different behavior and enrichment at the different stages of the polymerization process.

The explanation for the measured activity ratios could be over self-absorption phenomenon, but only to a certain extent. Namely, practice showed, and software for efficiency transfer calculation confirmed, that if density of the sample changes for $1 \%$ it results in similar change in detection efficiency.

In a previously published paper Puertas et al. (44) showed that activity concentration of the hydrated or activated end product by unit of mass is slightly lower than in the anhydrous material because of the presence of moisture. The extent of the decline

TABLE 3. Activity concentration (in $\mathrm{Bq} / \mathrm{kg}$ ) of natural radionuclides in kaolin (K), metakaolin (MK) and geopolymer (GP) with associated measurement uncertainties $(\mathrm{k}=1)$

\begin{tabular}{lccccc}
\hline & \multicolumn{3}{c}{ Activity concentration $[\mathbf{B q} / \mathbf{k g}]$} & \multicolumn{2}{c}{ Activity ratio } \\
\cline { 2 - 5 } & $\mathbf{K}$ & $\mathbf{M K}$ & $\mathbf{G P}$ & MK/K & GP/K \\
\hline${ }^{137} \mathbf{C s}$ & $<0.5$ & $<0.5$ & $<0.5$ & \\
${ }^{210} \mathbf{P b}$ & $250 \pm 15$ & $327 \pm 19$ & $163 \pm 10$ & $1.31 \pm 0.15$ & $0.65 \pm 0.08$ \\
${ }^{214} \mathbf{P b}$ & $216 \pm 11$ & $345 \pm 18$ & $156 \pm 8$ & $\mathbf{1 . 6 0} \pm 0.18$ & $\mathbf{0 . 7 2} \pm 0.07$ \\
${ }^{214} \mathbf{B i}$ & $214 \pm 12$ & $338 \pm 18$ & $153 \pm 8$ & $1.58 \pm 0.17$ & $0.72 \pm 0.08$ \\
${ }^{226} \mathbf{R a}$ & $215 \pm 11$ & $342 \pm 18$ & $154 \pm 8$ & $1.59 \pm 0.17$ & $0.72 \pm 0.07$ \\
${ }^{238} \mathbf{U}$ & $363 \pm 20$ & $432 \pm 24$ & $204 \pm 12$ & $1.19 \pm 0.13$ & $0.56 \pm 0.06$ \\
${ }^{235} \mathbf{U}$ & $22 \pm 2$ & $24 \pm 3$ & $11 \pm 1.6$ & $1.12 \pm 0.24$ & $\mathbf{0 . 5 2} \pm 0.12$ \\
$\left.{ }^{232} \mathbf{T h}{ }^{228} \mathbf{A c}\right)$ & $87 \pm 5$ & $115 \pm 7$ & $55 \pm 4$ & $1.32 \pm 0.16$ & $0.64 \pm 0.08$ \\
${ }^{212} \mathbf{P b}$ & $90 \pm 5$ & $115 \pm 6$ & $58 \pm 3$ & $1.28 \pm 0.14$ & $0.64 \pm 0.07$ \\
${ }^{212} \mathbf{B i}$ & $90 \pm 8$ & $120 \pm 9$ & $56 \pm 6$ & $1.33 \pm 0.19$ & $0.62 \pm 0.11$ \\
${ }^{208} \mathbf{T l}$ & $31 \pm 2$ & $41 \pm 2$ & $20 \pm 1$ & $1.31 \pm 0.15$ & $0.64 \pm 0.07$ \\
${ }^{40} \mathbf{K}$ & $193 \pm 11$ & $214 \pm 12$ & $120 \pm 10$ & $\mathbf{1 . 1 1} \pm 0.13$ & $0.62 \pm 0.09$ \\
\hline
\end{tabular}


TABLE 4. Calculated radium equivalent activity, external radiation hazard index, external absorbed dose rate and annual effective dose rate $(13,14,29,30)$

\begin{tabular}{|c|c|c|c|c|}
\hline Sample & $\mathbf{R a}_{\mathrm{eq}}(\mathrm{Bq} / \mathrm{kg})$ & $\mathrm{H}_{\mathrm{ex}}(\mathrm{Bq} / \mathrm{kg})$ & $\dot{D}$ (nGy/h) & EDR (mSv/y) \\
\hline Kaolin (K) & 353.699 & 0.962 & 159.685 & 0.196 \\
\hline Metakaolin (MK) & 522.499 & 1.418 & 236.207 & 0.290 \\
\hline Geopolymer (GP) & 241.89 & 0.657 & 109.372 & 0.134 \\
\hline
\end{tabular}

TABLE 4a. Calculated external absorbed dose rate and annual effective dose rate (31)

\begin{tabular}{lcc}
\hline Sample & $\dot{\boldsymbol{D}}(\mathbf{n G y / h})$ & EDR $(\mathrm{mSv} / \mathrm{y})$ \\
\hline Kaolin (K) & 308.5 & 1.512 \\
Metakaolin (MK) & 457.93 & 2.244 \\
Geopolymer (GP) & 211.78 & 1.038 \\
\hline
\end{tabular}

corresponds closely to water content in examined samples. For example, activity concentration is lower per unit of mass in hydrated cements than in their anhydrous components for $40-50 \%$. They have confirmed this fact on a series of samples. Results presented in this paper confirmed that, but in our research we further monitored the change in radioactivity after the polymerization process. For process of polymerization we thermally treated kaolin (initiation of kaolin) to get metakaolin (the initiator) who activated and started process of polymerization in alkali environment. With heat treatment, crystalline structures appear which make the geopolymer matrix double phased, keeping the amorphous part predominant. Natural radioactivity of metakaolin is the largest, since the thermal treatment leads to water loss while during of geopolymerization process gets a final product with the lowest radioactivity.

\subsubsection{Dose calculation}

Table 4 presents the total values of the radium equivalent activity $\left(\mathrm{Ra}_{\mathrm{eq}}\right)$, radiation hazards $\left(\mathrm{H}_{\mathrm{ex}}\right)$, absorbed dose rate (D), and annual effective dose rate (EDR) of kaolin (K), metakaolin (MK) and geopolymer (GP) samples.

The calculations were performed in accordance with UNSCEAR 2000 (14) under the assumption that investigated materials occurs in the environment. If these materials are treated as a raw material for building material or construction material itself, absorbed dose rate and EDR were calculated in accordance with (31), and results are given in Table 4a.

The highest values were observed for metakaolin (MK), and this can be generally explained by thermal treatment which gives higher activities values of natural radionuclides obtained by metakaolin gamma spectroscopy analysis (Table 3). The lowest values were observed for the synthesized material, and from the radiological point of view it could be recommended as a promising construction material. In the last 10 years a database of activity concentration measurements of natural radionuclides ${ }^{226} \mathrm{Ra}$, ${ }^{232} \mathrm{Th}$ and ${ }^{40} \mathrm{~K}$ ) in building material was established. This database comprises about 10000 samples of materials used in the construction industry in 26 of 27 European Member States (45). The values of activity concentration of natural radionuclides $\left({ }^{226} \mathrm{Ra},{ }^{232} \mathrm{Th}\right.$ and $\left.{ }^{40} \mathrm{~K}\right)$ in our investigated samples are in the range of results that have been published in the above reference.

\section{CONCLUSION}

XRD, FTIR, XPS analysis of the investigated samples showed mineralogical composition, new chemical bondings, as well as the present phase of the metakaolin that was used as a monomer in the polymerization process. Using XRD analysis mineralogical composition of samples were provided. The important thing is a quartz reflection of the raw material that remained after the polymerization process. FTIR and XPS analysis revealed formation of new chemical bonds in the geopolymer samples. XPS analysis confirmed that Si to Al ratio (Si/Al) is lowest in metakaolin (1.47) and in synthesized geopolymer material has been recorded the highest ratio of $\mathrm{Si} / \mathrm{Al}$ (1.88). After alkaline activation of metakaolin, the decrease of specific activity of naturally occurring radionuclides was measured/detected in synthesized geopolymer. This research confirmed that during the polymerization process the natural radioactivity was reduced, i.e. process of metakaolin activation has an influence on natural radioactivity of precursor. The material with less natural radioactivity was obtained by polymerization process, or geopolymerization and aging this material for 28 days. From the aspect of the natural radioactivity, obtained material (geopolymer) can be recommended as a potential building material.

Presented results were obtained in the preliminary phase of a comprehensive investigation of physical-chemical and radiological characteristic of kaolin and its polymerization products. Obtained results have given the guidance for further optimization of the polymerization process in order to confirm and explain changes in radioactivity concentrations. 


\section{ACKNOWLEDGEMENT}

This work was supported by the Ministry of Education, Science and Technological Development of Republic of Serbia, Project numbers: [III 45012 and III 45005].

\section{REFERENCE}

1. Kirchner, A.V.; Harmuth, H. (2004) Investigation of Geopolymer Binders with respect to Their Application for Building Materials. Ceram. Silik. 48 [3], 117-120.

2. Malek, R.I.A.; Roy, D.M. (1996) Reducing the greenhouse effect through new cements. In: Enviromental issues and waste management technologies in the ceramic and nuclear industries symposium Indianapolis, Indianapolis, p.333-343.

3. Davidovits, J. (1994) in: Proceedings First International Conference on Alkaline Cements and Concretes, Scientific Research Institute on Binders and Materials, Kiev State Technical University, Kiev, Ukraine.

4. Palomo, A.; Blanco-Varela, M.T.; Granizo Puertas, M.L.F.; Vazquez, T.; Grutzeck, M.W. (1999) Chemical Stability of Cementitious Materials based on Metakaolin. Cem. Concr. Res. 20 [7], 997-1004. https://doi.org/10.1016/ S0008-8846(99)00074-5

5. Odler, I. (2000) Special inorganic cements. E\&FN SPON, New York.

6. Shi, C.; Fernández-Jiménez, A.; Palomo, A. (2011) New cements for the 21st century: The pursuit of an alternative to Portland cement. Cem. Concr. Res. 41[7], 750-763. https://doi.org/10.1016/j.cemconres.2011.03.016

7. Miranda, J.M.; Jimenez, A.F. ; Gonzalez, J,A.; Palomo, A. (2005) Corrosion resistance in activated fly ash mortars. Cem. Concr. Res. 35, 1210-1217. https://doi.org/10.1016/j. cemconres.2004.07.030

8. Davidovits, J. (1994) Global warming impact on the cement and aggregates industries. World Resource Review 6 [2], 263-278

9. Saraswathy, V.; Muralidharan. S.; Thangavel, K.; Srinivasan, S. (2003) Influence of activated fly ash on corrosion-resistance and strength of concrete. Cem. Concr. Compos. 25[7], 673-680. https://doi.org/10.1016/ S0958-9465(02)00068-9

10. Saraswathy, V.; Karthick, S.P. (2013) A state-of-the-art review on the durability of silica fume-blended concretea boon to the construction industry. Corros. Rev 31[3-6], 123-134. https://doi.org/10.1515/corrrev-2013-0017

11. Duxson, P.; Fernández-Jiménez, A.; Provis, J.L.; Lukey, G.C.; Palomo, A.; Deventer, Van J.S.J. (2007) Geopolymer technology: the current state of the art. J. Mater. Sci. 42, 2917-2933. https://doi.org/10.1007/s10853-006-0637-z

12. Building Materials in Civil Engineering (2011) A volume in Woodhead Publishing Series in Civil and Structural Engineering, Ed: Haimei Zhang, Published by Woodhead Publishing Limited, Cambridge, UK, pp. 7-28.

13. O'Brien, R.S.; Cooper, M.B. (1998) Technologically enhanced naturally occurring radioactive material (NORM): pathway analysis and radiological impact. Appl. Radiat. Isot. 49. 227-239. https://doi.org/10.1016/ S0969-8043(97)00244-3

14. UNSCEAR (2000) Sources and effects of ionizing radiation-United Nations Scientific Committee on the effects of Atomic Radiation, UNSCEAR 2000 Report to the General Assembly with Scientific Annexes, United Nations, New York.

15. Merdanoglu, B.; Altinsoy, N. (2006) Radioactivity concentration and dose assessment for soil samples from Kestanbol granite area, Turkey. Radiat. Prot. Dosimetry 121, 399-405. https://doi.org/10.1093/rpd/ncl055

16. Nuccetelli, C.; Risica, S. (2008) Thorium series radionuclides in the environment: measurement, dose assessment and regulation. Appl. Radiat. Isot. 66, 1657-1660. https:// doi.org/10.1016/j.apradiso.2008.01.024
17. Riise, G. (1990) A study of radionuclide association with soil components using a sequential extraction procedure. J. Radioanal. Nucl. Chem. 142, 531-538. https://doi. org/10.1007/BF02040324

18. Schmidt, U. (2003) Enhancing phytoextraction: the effect of chemical soil manipulation on mobility, plant accumulation, and leaching of heavy metals. J. Environ. Qual. 32, 1939-1954. https://doi.org/10.2134/jeq2003.1939

19. Ramli, A.T. Wahab M.A. Hussein A. Wood, K. (2005) Environmental 238U and 232Th concentration measurements in an area of high level natural background radiation at Palong, Johor, Malaysia. J Environ. Radioact. 80, 287-304. https://doi.org/10.1016/j.jenvrad. 2004.06.008

20. Tsabaris, C.; Eleftheriou, G.; Kapsimalis, V.; Anagnostou, C.; Vlastou, R.; Durmishi, C.; Kedhi, M.; Kalfas, C.A. (2007) Radioactivity levels of recent sediments in the Butrint Lagoon and the adjacent coast of Albania. Appl. Radiat. Isot. 65 [4], 445-453. https://doi.org/10.1016/j. apradiso.2006.11.006

21. Frattini, P.; de Vivo, B.; Lima,A.; Cicchella, D. (2006) Elemental and gamma-ray surveys in the volcanic soils of Ischia Island, Italy. Geochem Explor. Environ. A 6 [4], 325-339.

22. Beretka, J.; Mathew, P.J. (1985) Natural radioactivity of Australian building materials, industrial wastes and by-products. Health Phys. 48, 87-95. https://doi. org/10.1097/00004032-198501000-00007

23. World Health Organization. WHO (2009) Handbook on Indoor Radon: A Public Health Perspective.WHO, Geneva, 2009. Available at http://www.who.int/ionizing_radiation/ env/radon/en/.

24. International Commission on Radiological Protection (2006) Low-dose extrapolation of radiation-related cancer risk. Publication 99. Amsterdam, the Netherlands: Elsevier.

25. Nenadović, S.; Nenadović, M.; Kljajević, Lj.; Vukanac, I.; Poznanović, M.; Radosavljević, A.M.; Pavlović, V. (2012) Vertical distribution of natural radionuclides in soil: Assessment of external exposure of population in cultivated and undisturbed areas. Sci. Total. Environ. 429, 309-316. https://doi.org/10.1016/j. scitotenv.2012.04.054

26. Vukanac, I.; Đurašević, M.; Kandić, A.; Novković, D.; Nađđerđ, L.; Milošević, Z. (2008) Experimental Determination of the HPGe spectrometer Efficiency Curve. Appl Radiat. Isotop. 66, 792-795. https://doi.org/ 10.1016/j.apradiso.2008.02.039

27. IAEA (1989) Measurement of Radionuclides in Food and the Environment, Technical Report Series No 295, Vienna, Austria.

28. Debertin K, Schötzing U (1990) Bedeutungvon Summationskorrektionen bei der GammastrahlenSpektrometrie mit Germaniumdetektoren. PTB-Bericht PTB-Ra-24, Braunschweig, Germany; Firestone RB8th ed. New York: Wiley-Interscience; Table of Isotopes.

29. Mulwa, B. M.; Maina, D. M.; Patel, J. P. (2013) Radiological Analysis of Suitability of Kitui South Limestone for use as Building Material. International Journal of Fundamental Physical Sciences. 3 [2], 32-35.

30. Ajayi, J. O.; Jere, P.; Balogun, B. B. (2013) Assessment of Radiological Hazard Indices of Building Materials in Ogbomoso, South-West Nigeria. Environ. Nat. Resources Research. 3 [2], 128-132. https://doi.org/10.5539/enrr. v3n2p128

31. UE Radiation protection 112 (1999) Radiological Protection Principles concerning the Natural radioactivity of Building Materials.

32. Davidovits, J. (2008) Geopolymer Chemistry and Applications, 2nd ed. Institut Géopolymère, SaintQuentin, France.

33. Barrios, J.; Plan on, A.; Cruz, M.I.; Tehoubar, C.; (1977) Qualitative and quantitative study of stacking faults in a hydrazine treated kaolinite--Relationship with the infrared spectra. Clays Clay Miner. 25, 422-429. https://doi. org/10.1346/CCMN.1977.0250608 
34. Rouxhet, R.G.; Samudaeheata, N.; Jacogs, H.; Anton, O. (1977) Attribution of the OH stretching bands of kaolinite. Clay Miner. 12 [2], 171-179.

35. Nuntiya, A.; Prasanphan, S. (2006) The rheological behavior of kaolin uspensions, Chiang Mai Journal of Science $33,271-281$.

36. Worasith, N.; Goodman, B.A.; Jeyashoke, N.; Thiravetyan, P. (2011) Decolorization of Rice Bran Oil using Modified kaolin. J. Am. Oil Chem. Soc. 88, 2005-2014. https://doi. org/10.1007/s11746-011-1872-2

37. Ekkose, G.I. (2005) Fourier Transform infrared spectrophotometry and X-ray powder diffractometry as complementary techniques in characterizing clay size fraction of kaolin. J. Appl. Sci. Environ. Manag. 9 [2], 43-48.

38. Farmer, V.C.; Russell, J.D. (1964) The infrared spectra of layered silicates. Spectrochimica Acta 20, 1149-1173. https://doi.org/10.1016/0371-1951(64)80165-X

39. Hochela, Jr. M.F.; Brown, Jr. G. (1988) Aspects of silicate surface and bulk structure analysis using X-ray photoelectron spectroscopy. Geochem. Cosmochem. Acta 52, 1641. https://doi.org/10.1016/0016-7037(88)90232-3

40. Kanuchova, M.; Kozakova, L.; Drabova, M.; Sisol, M.; Estokova, A.; Kanuch, J.; Skvarla, J. (2015) Monitoring and Characterization of Creation of Geopolymers Prepared
From Fly Ash and Metakaolin by X-Ray Photoelectron Spectroscopy Method. Environ. Prog. Sustain. Energy 34, 841. https://doi.org/10.1002/ep.12068

41. Paparazzo, E. (1996) On the XPS analysis of Si-OH groups at the surface of Silica. Surf. Interf. Anal. 24, 729. https://doi. org/10.1002/(SICI) 1096-9918(19960930)24:10<729::AIDSIA183>3.0.CO;2-P

42. Wagner, C.D.; Naumkin, A.V.; Kraut-Vass, A.; Allison, J.W.; Powell, C.J.; Rumble, J.R. Jr. (2003) NIST Standard Reference Database 20, Version 3.4 (web version) (http:/ srdata.nist.gov/xps/).

43. Xu, H.; van Deventer, J.S.J. (2003) Effect of Source Materials on Geopolymerization. Ind. En. Chem. Res. 42, 1698-1706. https://doi.org/10.1021/ie0206958

44. Puertas, F.; Alonso, M.M.; Torres-Carrasco, M.; Rivilla, P.; Gasco, C.: Yagüeb, L.: Suárez, J.A.; Navarro, N. (2015) Radiological characterization of anhydrous/hydrated cements and geopolymers. Constr. Build. Mater. 101, 11051112. https://doi.org/10.1016/j.conbuildmat.2015.10.074

45. Trevisi, R.; Risica, S.; Alessandro, M. D.; Paradiso, D.; Nuccetelli, C.; (2012) Natural radioactivity in building materials in the European Union: a database and an estimate of radiological significance. J Environ. Radioact. 105, 11-20. https://doi.org/10.1016/j.jenvrad.2011.10.001 